\title{
Bed Planting Techniques Improved Crop Yield by Efficient use of Added Nitrogen Fertilizer
}

\author{
Abdul Majeed ${ }^{1}$, Abid Niaz², Aysha Sameen ${ }^{3}$, Hafiz Basheer Ahmad', \\ Muhammad Younus ${ }^{1}$, Muhammad Aftab², Muhammad Arif ${ }^{2}$
}

10.18805/IJARe.A-599

\begin{abstract}
Background: Nitrogen fertilizer is imperative for rice and wheat growth and dry matter yield as compare to other macronutrients. Nitrogen is also added in high amount in every one of rice and wheat cultivation method. Effective uptake of added nitrogen by crops from soil supports in increasing crop growth and dry matter yield. Best $\mathrm{N}$ fertilizer utilization is indispensable for improving crop growth and to decrease environmental pollution.

Methods: A comparison of the utility of nitrogen fertilizer usage by plants in wheat and rice crops grown on beds and flat land was planned in the current investigation. Beds were manufactured with bed planter machine. The plant samples were collected, dried and digested with acid for mineral nutrients analysis after harvesting the crops.

Result: The results showed that the addition of $\mathrm{N}$ fertilizer ( $80 \mathrm{~kg} / \mathrm{ha})$ to the bed produced at par yield (4.51 $\mathrm{t} / \mathrm{ha})$ as obtained by an addition of $120 \mathrm{~kg} \mathrm{~N} / \mathrm{ha}$ in flat sowing. Planting of rice on bed plus furrow and adding $N(100 \mathrm{~kg} / \mathrm{ha})$ to the prescribed dosage of $N$ (150 kg / ha) in flat sowing produced at par yield. It concludes that by planting crops on beds without loss in yield, higher use of $\mathrm{N}$ fertilizer in crops can be minimized. Thus, bed planting strategies effectively and indirectly minimize nitrous oxide emissions from applied nitrogen fertilizers in wheat and rice crop fields through increasing the usage of added $\mathrm{N}$ fertilizer through plants.
\end{abstract}

Key words: Bed planting, Grain yield, Nitrogen contents, Rice, Wheat.

\section{INTRODUCTION}

A big cause of greenhouse gases (GHG) emissions into the atmosphere has historically been grain growing agricultural activities. Global warming is a proven reality and GHG emissions are projected to be the main causes of climate change due to humans and agriculture practices (IPCC, 2013; Ahlawat and Kaur, 2015). Nitrogenous (N) fertilizers play a major role in increasing the production of crop biomass and grain yields. Injudicious and indiscriminate application of $\mathrm{N}$ fertilizer has therefore led to food, soil and water contamination in many crops (Chaudhuary et al., 2020). Reducing undue $\mathrm{N}$ pollution and damages in the $21^{\text {st }}$ century poses a significant environmental threat (Wightman, 2015). Participation of Pakistan is invaluable for worldwide efforts to decrease N fertilizer-related GHG pollution, as Pakistan is the agricultural country and uses a large amount of $\mathrm{N}$ fertilizer to grow crops. Nitrous oxide $\left(\mathrm{N}_{2} \mathrm{O}\right)$ is known as a significant source of $\mathrm{GHG}$ and induces 298 times greater global warming compared to $\mathrm{CO}_{2}$ (IPCC, 2013). As opposed to other macronutrients, nitrogen fertilizer is imperative for rice and wheat growth and dry matter yield. Nitrogen is also strongly applied to both of the rice and wheat cultivation methods (Snyder et al., 2009; Bond et al., 2008; Singh et al., 2014; Majeed et al., 2017). The successful absorption of added nitrogen by soil crops promotes the production of dry matter in growing crop growth. Usage of the best $\mathrm{N}$ fertilizer is important to improve crop growth and reduce environmental emissions. The lower amount of $\mathrm{N}$ fertilizer can result in lower crop biomass, grain quality and for this
'Sugarcane Research Institute, Ayub Agricultural Research Institute, Faisalabad, Pakistan.

${ }^{2}$ Soil Chemistry Section, Institute of Soil Chemistry and Environmental Sciences, Ayub Agricultural Research Institute, Faisalabad, Pakistan. ${ }^{3}$ National Institute of Food Science and Technology, University of Agriculture Faisalabad, Pakistan.

Corresponding Author: Abdul Majeed, Sugarcane Research Institute, Ayub Agricultural Research Institute, Faisalabad, Pakistan. Email: drmajeed1805@gmail.com

How to cite this article: Majeed, A., Niaz, A., Sameen, A., Ahmad, H.B., Younus, M., Aftab, M. and Arif, M. (2021). Bed Planting Techniques Improved Crop Yield by Efficient use of Added Nitrogen Fertilizer. Indian Journal of Agricultural Research. 55(5): 542-548. DOI: 10.18805/IJARe.A-599.

Submitted: 25-09-2020 Accepted: 27-03-2021 Online: 22-04-2021

reason, lower income. If a higher dosage of $\mathrm{N}$ fertilizer is used, it leads to a decline in NUE and raises the risk of $\mathrm{N}$ depletion in the form of $\mathrm{N}_{2} \mathrm{O}$ pollution (Ju et al., 2009, Ishaq et al., 2001; Xing and Zhu, 2000). One approach to the production of greater grain yield with low nitrogen inputs is to increase NUE (Kukal and Aggarwal, 2003; Naresh et al., 2014). Flood irrigation methods for planting wheat and rice on a flat surface resulted in less water and less effective use of fertilizers (lqbal et al. 2005, Mollah et al. 2009). Higher wheat plant biomass, dry matter yield and fertilizer usage efficacy is demonstrated by bed and furrow irrigation techniques (Majeed et al., 2015). N fertilizer addition can 
have a direct effect on crop yields and GHG emissions (Liang et al., 2013; Li et al., 2011; Zou et al., 2005). Different strategies such as controlled or gradual release of urea and various nitrification inhibitors are used to improve NUE, yield crops and limit GHG emissions (Majumdar, 2003). The aim of this experiment was to increase NUE with various application rates of nitrogen fertilizer under bed and flat planting techniques and to minimize indirect nitrous oxide emissions from cultivated fields.

\section{MATERIALS AND METHODS}

Field experiment was carried out at Soil Chemistry Section, Ayub Agricultural Research Institute, Faisalabad Pakistan. Weather data presenting mean monthly maximum temperature and total rainfall during experimental period of wheat and rice crop showed fluctuations (Fig 7). The collected soil sample was air dried, grinded and passed through the $02 \mathrm{~mm}$ sieve. Finally the sample was analyzed according to different soil characteristics (Table 1). Using commonly used laboratory techniques as described in the U.S. Lab Salinity (1954) and Page (1982) soil characteristics were assessed. Electrical conductivity (EC) and $\mathrm{pH}$ were assessed by adding soil at 1:5, soil: water, ratio to deionized water (Nelson and Sommers, 1982). Available soil P (Olsen et al., 1954) and extractable K (Rowell, 1994). Using the hydrometer method described by Bouyoucos (1962), particle size analysis was carried out and the values obtained from soil particles were plotted against the texture triangle of the soil texture class (Table 1). Following the traditional land planning, beds were manufactured with machine to plant beds. Wheat crop seeds (Photographs $A$ and $B$ ) and rice nursery seeds (Photographs $C$ and $D$ ) were grown on the flat surface and in rows / lines on the bed. Every plot was harvested randomly from nine square meters of land. The plant samples were collected, dried and digested with acid for analysis after harvesting the crops (Jackson, 1962). In plant samples phosphorous was calculated using a colorimetric technique using a spectrophotometer (IRMECOU-2020). After calibration, samples were analyzed with a $410 \mathrm{~nm}$ wavelength spectrophotometer. The absorbed light rate was used in plant samples to show the concentration of $P$ (Allen et al., 1986). To test potassium, a flamephotometer was used. A series of standards for drawing up a standard curve $(0,10,20,30,40$ and 50 ppm) was prepared. The flame photometer $\mathrm{K}$ values were associated with the standard curve and the corresponding total quantity was calculated (Ryan et al., 2001). The test for nitrogen was performed using the Kjeldahl process (Jackson, 1962). All treatment was replicated three times and Statistics 8.1 software was used to evaluate statistical data (Steel and Torrie, 1997).

\section{RESULTS AND DISCUSSION}

Data revealed (Fig 1) that adding $N(80 \mathrm{~kg} / \mathrm{ha})$ to the bed provided a non-significant yield $(4.51 \mathrm{t} / \mathrm{ha})$ of $\mathrm{N}(120 \mathrm{~kg} / \mathrm{ha})$ in flat sowing (4.63 t/ha) as recommended. The rising application of nitrogen (up to $120 \mathrm{~kg} / \mathrm{ha}$ ) on beds substantially increased the crop yield $(5.1 \mathrm{t} / \mathrm{ha})$ than the yield of the traditional flat wheat sowing system by broad casting $(4.63 \mathrm{t} / \mathrm{ha})$. It revealed that with bed planting of

Table 1: Soil physicochemical properties.

\begin{tabular}{lcccrr}
\hline Experiment & $\mathrm{pH}_{\mathrm{s}}$ & $\begin{array}{c}\mathrm{EC}_{\mathrm{e}} \\
\left(\mathrm{dS} \mathrm{m} \mathrm{m}^{-1}\right)\end{array}$ & $\begin{array}{c}\text { O.M } \\
(\%)\end{array}$ & $\begin{array}{c}\text { Av. P } \\
\left(\mathrm{mg} \mathrm{kg}^{-1}\right)\end{array}$ & $\begin{array}{c}\text { Av. K } \\
\left(\mathrm{mg} \mathrm{kg}^{-1}\right)\end{array}$ \\
\hline Wheat experiment & 8.11 & 1.57 & 0.67 & 8.74 & 224 \\
Rice experiment & 8.17 & 1.64 & 0.62 & 9.34 & Sandy clay loam \\
\hline
\end{tabular}

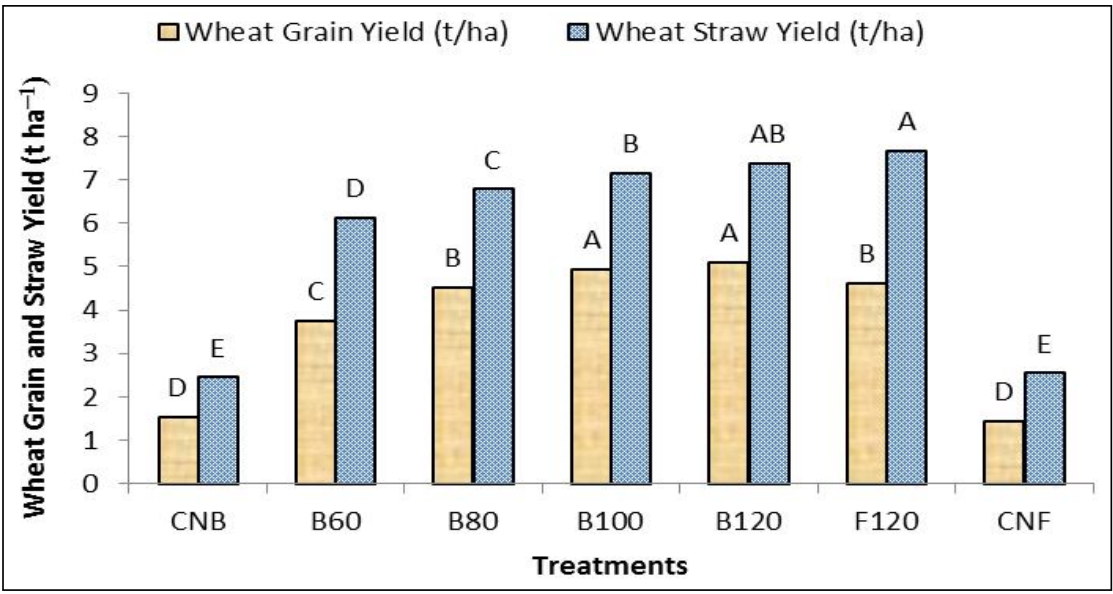

Fig 1: Wheat grain and straw yield $\left(\mathrm{t} \mathrm{ha}^{-1}\right)$ planted on beds and flat soil surface.

Note: T1= CNB (Control bed planting), T2= B60 (Bed planting N@60 kg/ha), T3= B80 (Bed planting N@80 kg/ha), T4= B100 (Bed planting N@100 kg/ha), T5= B120 (Bed planting N@120 kg/ha), T6= F120 (Flat planting N@120 kg/ha), T7= CNF (Control flat planting). According to the LSD test, dissimilar letters suggest substantial difference between treatments at $\mathrm{p} \leq 0.05$. 
wheat, around $1 / 3$ of $\mathrm{N}$ fertilizer can be saved. Data (Fig 1) on straw yield showed that the maximum straw yield $(7.66 \mathrm{t} / \mathrm{ha})$ was achieved in flat sowing with $120 \mathrm{~kg} / \mathrm{ha}$ addition of nitrogen. Results concerning the yield of rice paddy (Fig 2) showed that the transplantation of rice on bed plus furrows and $100 \mathrm{~kg} / \mathrm{ha} \mathrm{N}$ addition yielded a higher yield (3.91 t/ha) as obtained by the prescribed dose of $\mathrm{N}(150 \mathrm{~kg} / \mathrm{ha})$ addition in traditional flat transplantation (3.74 t/ha), both of which were equal to each other but substantial than all other levels of nitrogen. Raised beds offered favorable physical and chemical soil conditions for growing plant roots, increased plant use of nitrogen fertilizers and provided superior yields of wheat and rice grains as compared to flat methods (Naresh et al., 2014; Majeed et al., 2015). Higher yields of wheat and rice grain in bed techniques have been recorded due to higher nutrient uptake (Majeed et al., 2017). The water moves from furrow to up bed in the bed sowing process, which increases crop grain yield due to higher nutrient transport and uptake by crop compared to the flat process (Hobbs and Gupta 2003; Farooq et al., 2009). Data on the nutrient content of wheat leaves at the booting stage (Fig 3) showed that maximum $\mathrm{N}$ concentration (2.81 per cent) was observed when nitrogen was applied @ $120 \mathrm{~kg} / \mathrm{ha}$ to the bed, which was not significant when $100 \mathrm{~kg} / \mathrm{ha}$ of nitrogen was added to the beds, whereas it was substantial when nitrogen was applied @ 60 when planting in the bed and $120 \mathrm{~kg} / \mathrm{ha}$ while sowing flat (Fig 3). Maximum P content $(0.20 \%)$ was observed during treatment when nitrogen $(100$ $\mathrm{kg} / \mathrm{ha}$ ) was added to the bed which was non-significant when $120 \mathrm{~kg} / \mathrm{ha} \mathrm{N}$ was added to the flat and bed sowing,

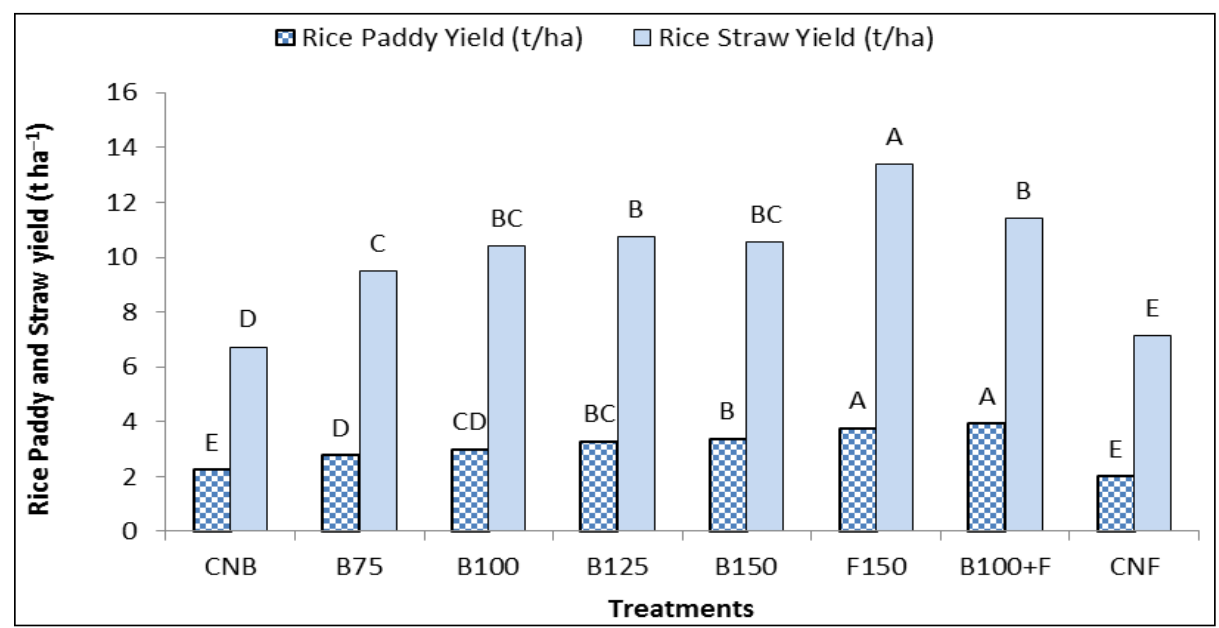

Fig 2: Rice paddy and straw yield ( $\mathrm{t} \mathrm{h}^{-1}$ ) planted on beds and flat soil surface.

Note: T1= CNB (Control bed planting), T2=B75 (Bed planting N@75 kg/ha), T3=B100 (Bed planting N@100 kg/ha), T4= B125 (Bed planting N@125 kg/ha), T5=B150 (Bed planting N@150 kg/ha), T6=F150 (Flat planting N@150 kg/ha), T7= B100+F (Bed+Furrow planting N@100 kg/ha), T8= CNF (Control flat planting). According to the LSD test, dissimilar letters suggest substantial difference between treatments at $\mathrm{p} \leq 0.05$.

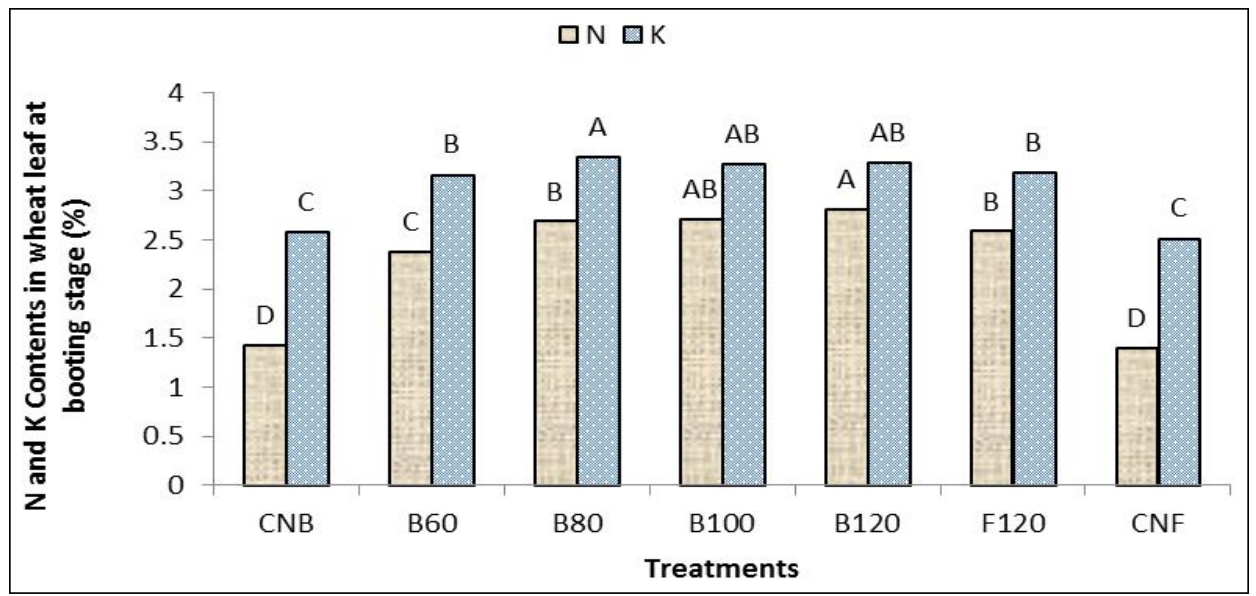

Fig 3: Nitrogen and Potassium contents (\%) in wheat leaf at booting stage.

Note: T1= CNB (Control bed planting), T2= B60 (Bed planting N@60 kg/ha), T3= B80 (Bed planting N@80 kg/ha), T4= B100 (Bed planting N@100 kg/ha), T5=B120 (Bed planting N@120 kg/ha), T6=F120 (Flat planting N@120 kg/ha), T7=CNF (Control flat planting). According to the LSD test, dissimilar letters suggest substantial difference between treatments at $p \leq 0.05$. 
while nitrogen was significant when 60 and $80 \mathrm{~kg} / \mathrm{ha}$ were added to the beds respectively (Fig 4). Data on N, P and $\mathrm{K}$ paddy contents (Fig 5 and 6 ) showed that the highest $\mathrm{N}$ concentration $(1.47 \%)$ was observed when nitrogen (150 kg/ha) was added to the bed, which was not significant when $100 \mathrm{~kg} / \mathrm{ha}$ of nitrogen was added to the bed $(1.36 \%)$, while the addition of nitrogen $(150 \mathrm{~kg} / \mathrm{ha})$ during flat transplantation was significant. A maximum $P$ content was observed $(0.22 \%)$ where nitrogen $(100 \mathrm{~kg} / \mathrm{ha})$ was added to the bed but was equal to other levels of nitrogen, while significant over control (Fig 6). As nitrogen (125 kg/ha) was added to the bed, the highest potassium concentration $(0.34 \%)$ was noted, which was at par with the T4 and T5 treatments but was substantial over control.

In the bed process, the higher nitrogen content in wheat leaves and rice paddy was correlated with superior crop biomass and slight loss of added $\mathrm{N}$ fertilizer. Greater use of $\mathrm{N}$ fertilizer by crop was found in the bed system (Jat et al., 2011; Majeed et al., 2017). Due to good mineralization of applied and indigenous soil nutrients, higher nitrogen utilization and crop yield were observed in the bed plantation process. In bed method plant roots take up efficiently added $\mathrm{N}$ fertilizer than flat method, even if $\mathrm{N}$ fertilizer was added in lower amounts indicating decrease in nitrogen losses (Mollah et al., 2009 and Jat et al., 2011).

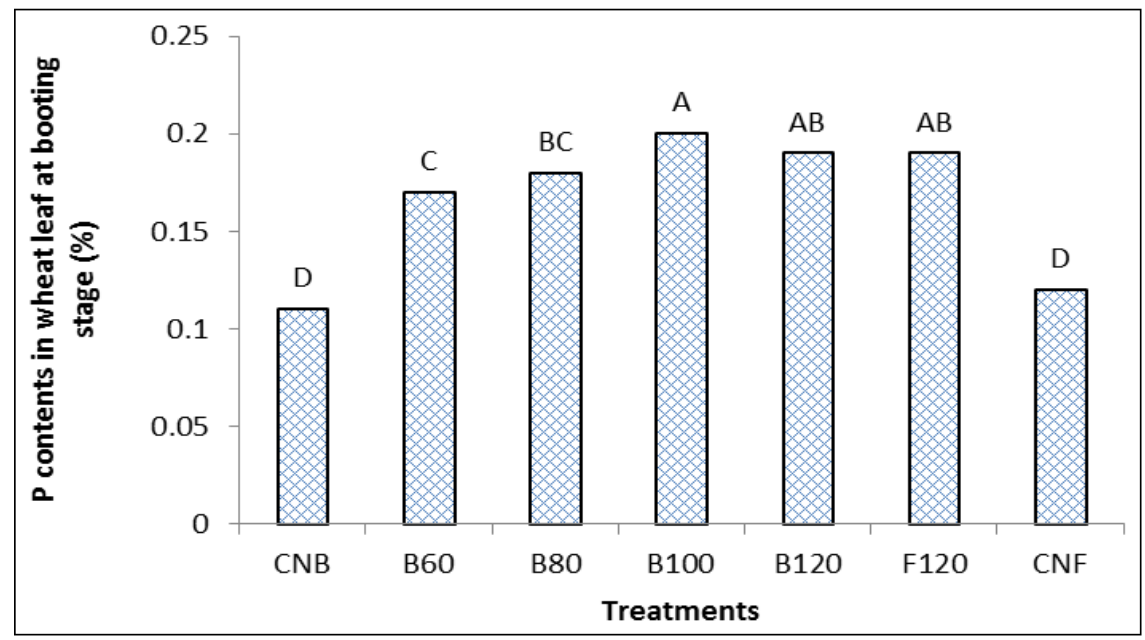

Fig 4: Phosphorus contents (\%) in wheat leaf at booting stage.

Note: T1= CNB (Control bed planting), T2=B60 (Bed planting N@60 kg/ha), T3=B80 (Bed planting N@80 kg/ha), T4= B100 (Bed planting N@100 kg/ha), T5=B120 (Bed planting N@120 kg/ha), T6=F120 (Flat planting N@120 kg/ha), T7= CNF (Control flat planting). According to the LSD test, dissimilar letters suggest substantial difference between treatments at $p \leq 0.05$.

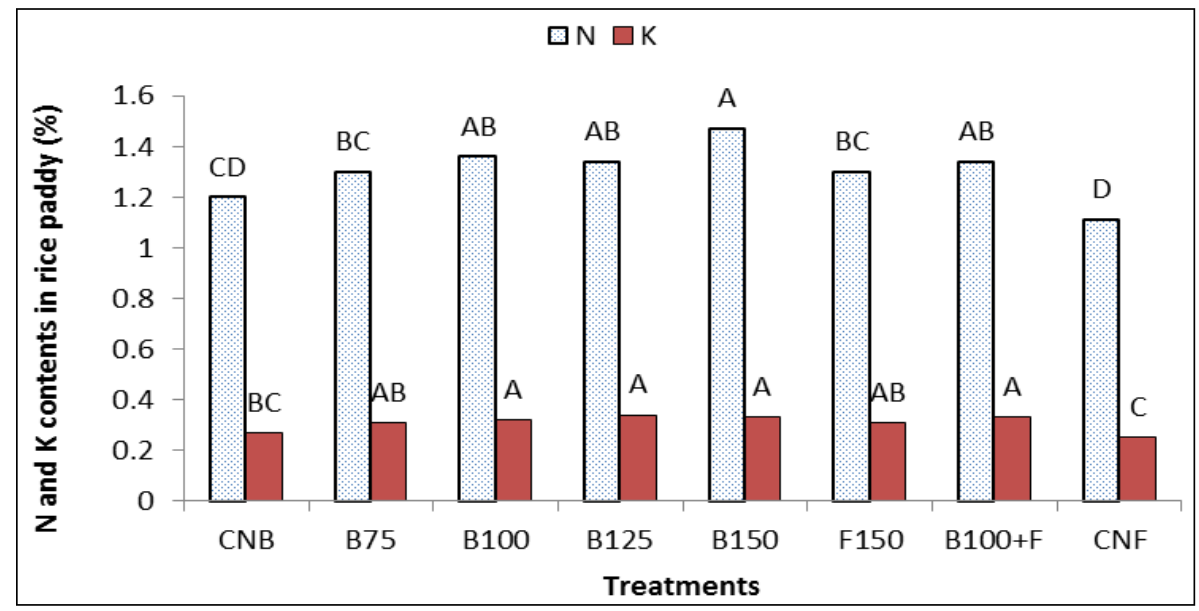

Fig 5: Nitrogen and Potassium contents (\%) in rice paddy.

Note: T1= CNB (Control bed planting), T2= B75 (Bed planting N@75 kg/ha), T3= B100 (Bed planting N@100 kg/ha), T4= B125 (Bed planting N@125 kg/ha), T5=B150 (Bed planting N@150 kg/ha), T6= F150 (Flat planting N@150 kg/ha), T7= B100+F (Bed+Furrow planting N@100 kg/ha), T8= CNF (Control flat planting). According to the LSD test, dissimilar letters suggest substantial difference between treatments at $\mathrm{p} \leq 0.05$. 


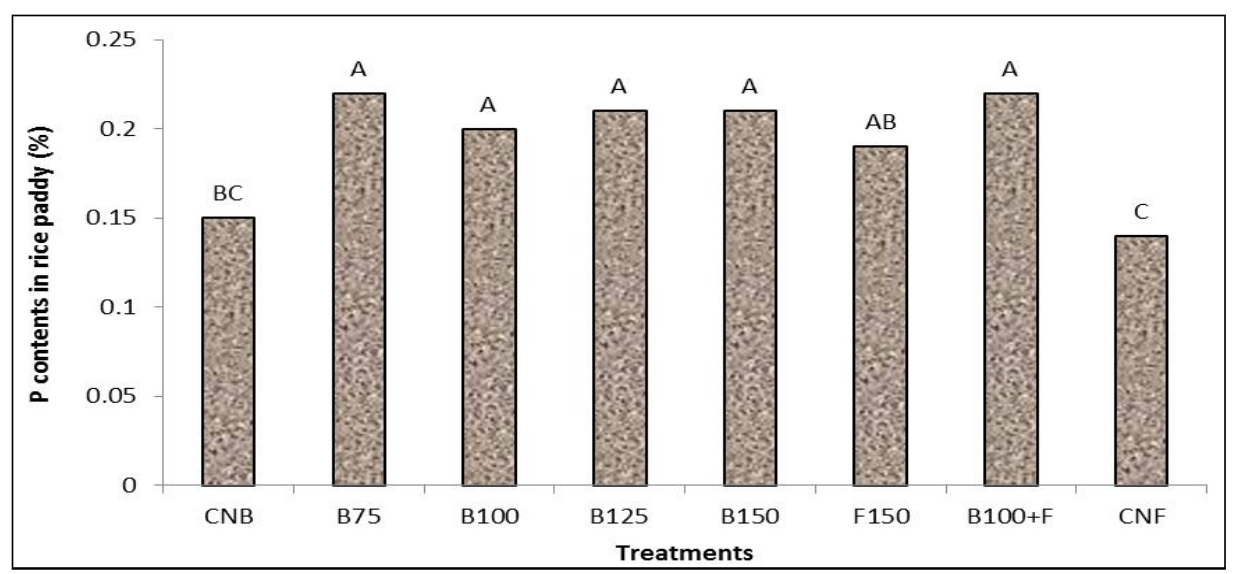

Fig 6: Phosphorus contents (\%) in rice paddy.

Note: T1= CNB (Control bed planting), T2= B75 (Bed planting N@75 kg/ha), T3= B100 (Bed planting N@100 kg/ha), T4= B125 (Bed planting N@125 kg/ha), T5=B150 (Bed planting N@150 kg/ha), T6=F150 (Flat planting N@150 kg/ha), T7=B100+F (Bed+Furrow planting N@100 kg/ha), T8= CNF (Control Flat planting). According to the LSD test, dissimilar letters suggest substantial difference between treatments at $p \leq 0.05$.

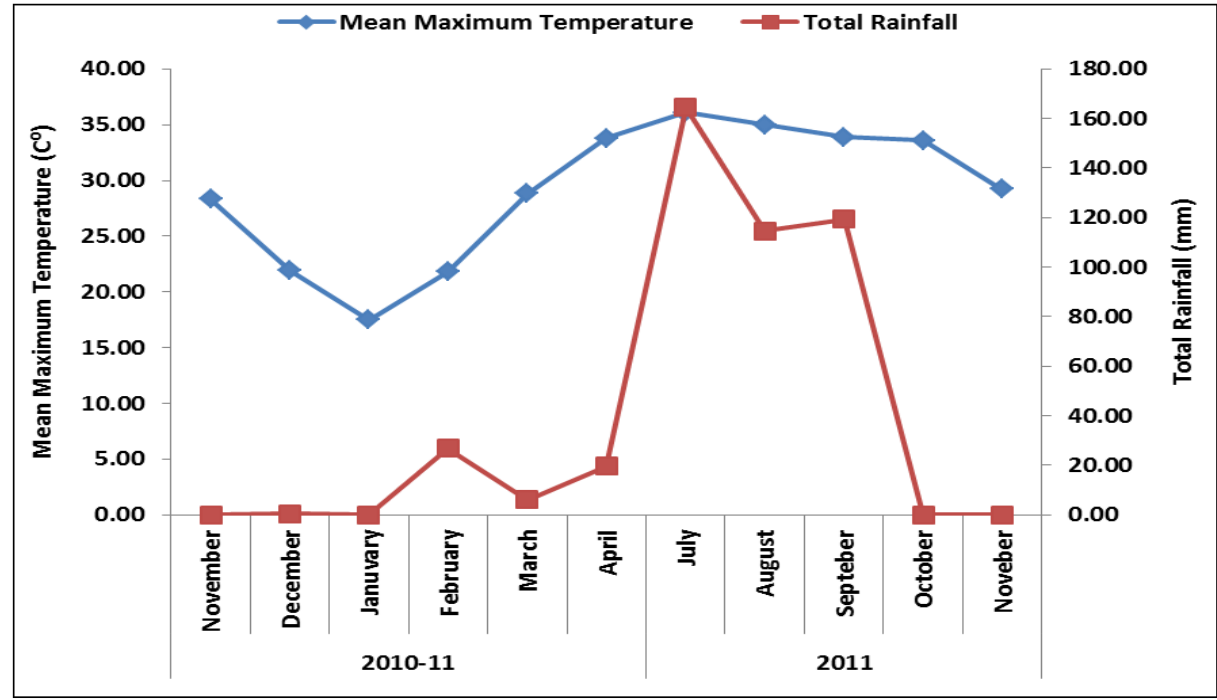

Fig 7: Weather data presenting mean monthly maximum temperature and total rainfall during experimental period of wheat and rice crop.

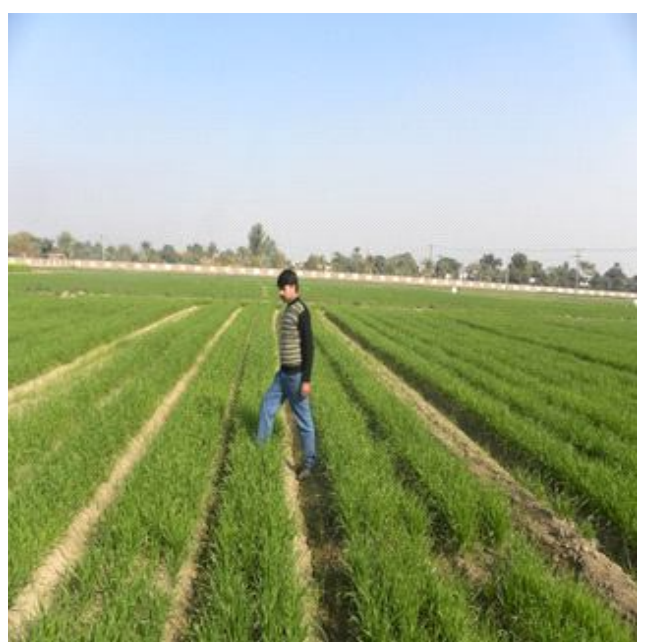

Photograph (A): Growth of wheat crop on bed.

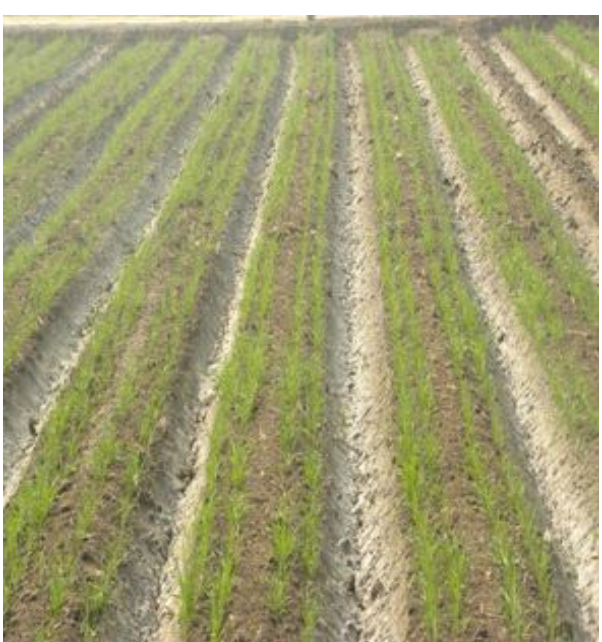

Photograph (B): Wheat crop on bed at early stage. 


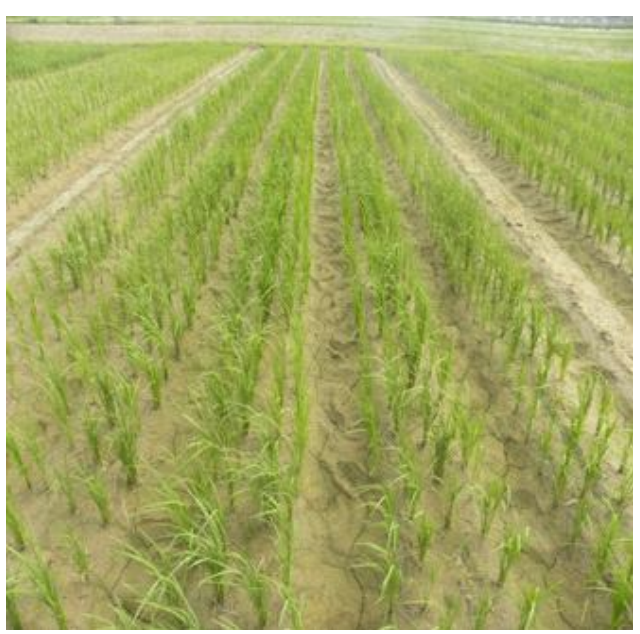

Photograph (C): Rice crop on beds at early stage.

\section{CONCLUSION}

Bed planting techniques increase the nitrogen content of crop plants and achieve higher wheat and rice grain yields at a lower fertilizer rate compared to flat sowing. It also suggests that bed planting technologies indirectly minimize greenhouse gas emissions from nitrogen by increasing the performance of the nitrogen-related fertilizer applied in wheat and rice crops. Therefore, in order to solve the issue of global warming by increased use of nitrogen fertilizer in crops and lower efficiency of use of $\mathrm{N}$, in future wheat and rice crops should be planted on beds to improve fertilizer utilization by crops.

\section{ACKNOWLEDGEMENT}

We are very thankful to Farm Manager of Soil Chemistry Section, Ayub Agricultural Research Institute Faisalabad, for providing the field area for this research work and also to the reviewers for the improvement of this manuscript.

\section{REFERENCES}

Ahlawat, S. and Kaur, D. (2015). Climate change and food production in North West India. Indian Journal of Agricultural Research. 49: 544-548.

Allen, S.E., Grimshaw, H.M and Rowland, P. (1986). Chemical Analysis. In: Methods in Plant Ecology. [Moore, P.D., Chapman, S.B. (Eds.)], Blackwell Scientific, Oxford, pp. 303-316.

Bond, J.A., Walker, T.W., Ottis, B.V. and Harrell, D.L. (2008). Rice seeding and nitrogen rate effects on yield and yield components of two rice cultivars. Agron. Journal. 100: 393-397.

Bouyoucos, (1962). Hydrometer method for making particle analysis of soil. Journal of Agronomy. 54: 464-465.

Chaudhuary, P., Chudhury, S.R., Das, A., Mandal, J., Ghosh, M., Acharya, S. and Homa, F. (2020). Productivity, profitability and greenhouse gas emission from rice wheat cropping system under different tillage and nitrogen management Practices. Indian Journal of Agricultural Research. 54(3): 285-292.

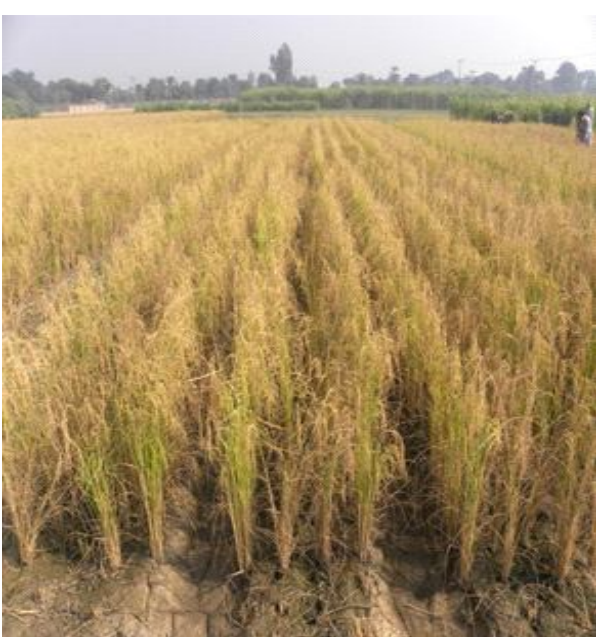

Photograph (D): Rice crop on beds at harvesting stage.

Farooq, M.N., Kobayashi, A., Wahid, O.I. and Basra, S.M.A. (2009). Strategies for producing more rice with less water. Advanced Agronomy. 101: 351-388.

Hassan, I., Hussain, Z. and Akbar, G. (2005). Effect of Permanent Raised Beds on Water Productivity for Irrigated MaizeWheat Cropping System. Australian Centre for International Agriculture Research Proceeding 121, of a workshop on Evaluation and Performance of Permanent Raised bed cropping systems in Asia, Australia and Mexico. 1-3 March, 2005, Grifith, NSW, Australia.

Hobbs, P.R. and Gupta, R.K. (2003). Resource-conserving Technologies for Wheat in the Rice-wheat System. In: Improving productivity and sustainability of rice-wheat systems: Issues and impact, American society of Agronomy Special Publication. vol. 65: 149-217.

IPCC, 2013. Climate Change (2013). The Physical Science Basis: Working Group I Contribution to the Fifth Assessment Report of the Inter-governmental Panel on Climate Change. Cambridge University Press, UK.

Iqbal, M., Akhtar, M., Mohammad, J., Shah, W., Nawaz, S.M. and Mahmood, K. (2005). Effect of tillage and fertilizer levels on wheat yield, nitrogen uptake and their correlation with carbon isotope discrimination under rain fed conditions in north-west Pakistan. Soil and Tillage Res. 80 47-57.

Ishaq, M., Ibrahim, M., Hassan, A., Saeed, M and Lal, R. (2001). Subsoil compaction effects on crops in Punjab, Pakistan II: Root growth and nutrient uptake of wheat and sorghum. Soil Till. Res. 60: 153-161.

Jackson, M.L. (1962). Soil Chemical Analysis. Prentice Hall: Inc. Englewood Cliffs, New Jersey. U.S.A.

Ju, X.T., Xing, G.X., Chen, X.P., Zhang, S.L., Zhang, L.J., Liu, X.J., Cui, Z.L., Yin, B., Christie, P. and Zhu, Z.L. (2009). Reducing environmental risk by improving $\mathrm{N}$ management in intensive Chinese agricultural systems. Proc. Natl. Acad. Sci. U.S.A. 106: 3041-3046.

Kukal, S.S. and Aggarwal, G.C. (2003). Puddling depth and intensity effects in rice-wheat system on a sandy loam soil I: development of subsurface compaction. Soil Till. Res. 72: 1-8. 
Li, D., Liu, M., Cheng, Y., Wang, D., Qin, J., Jiao, J., Li, H., Hu, F. (2011). Methane emissions from double-rice cropping system under conventional and no tillage in southeast China. Soil Till. Res. 113: 77-81.

Liang, X., Li, H., Wang, S., Ye, Y., Ji, Y., Tian, G., Van Kessel, C. and Linquist, B. (2013). Nitrogen management to reduce yield-scaled global warming potential in rice. Field Crops Res. 146: 66-74.

Jat, M.L., Gupta, R., Saharawat, Y.S. and Khosla, R. (2011). Layering precision land leveling and furrow irrigated raised bed planting: productivity and input use efficiency of irrigated bread wheat in indo-gangetic plains, Am. J. Plant Sci. 2: 578-588.

Majeed, A., Muhmood, A., Niaz, A., Javid, S., Ahmad, Z.A., Shah, S.S.H. and Shah, A.H. (2015). Bed planting of wheat (Triticum aestivum L.) improves nitrogen use efficiency and grain yield compared to flat planting. The crop journal. 3: $18-124$.

Majeed, A., Niaz, A., Muhmood, A., Ahmad, Z.A., Ilyas, M. and Wakeel, A. (2017). Nitrogen use efficiency, water saving and yield of rice transplanting on raised bed over traditional flat method. J. Plant Nutrition. DOI:10.1080/01904167. 2016.1240190.

Majumdar, D. (2003). Methane and nitrous oxide emission from irrigated rice fields: Proposed mitigation strategies. Curr. Sci. 84: 1317-1326.

Mollah, M.I.U., Bhuiya, M.S.U. and Kabir, M.H. (2009). Bed planting, a new crop establishment method for wheat in ricewheat cropping system. J. of Agri. and Rural Develop. 7: 23-31.

Naresh, R.K., Tomar, S.S., Kumar, D. Samsher, Purushottam, Singh, S.P., Dwivedi, A. and Kumar, V. (2014). Experiences with rice grown on permanent raised beds, effect of crop establishment techniques on water use, productivity, profitability and soil physical properties. Rice Science. 21: $170-180$.

Nelson, D.W. and Sommers, L.E. (1982) Total Carbon, Organic Carbon and Organic Matter. In: Methods of Soil Analysis, Part 2: chemical and Microbiological Properties, [(ed.) Klute, A.], Am. Soc. Agron, Madison WI. pp. 570-571.
Olsen, S.R., Cole, C.V., Watanabe, F.S. and Dean, L.A., (1954). Estimation of Available Phosphorus in Soils by Extraction with Sodium Bicarbonate. USDA. Circular/United States Department of Agriculture, Washington no. 939.

Page, A.L., Miller, R.H. and Keeny, D.R. (1982). Methods of soil analysis (Part 2). Chemical and microbiological properties. Agronomy 9. SSSA, Madison.

Rowell, D.L. (1994). Soil Science. Methods and Application. Longman Scientific and Technical, UK.

Ryan, P., Delhaize, E. and Jones, D. (2001). Function and mechanisms of organic anion exudation from plant roots. Annu. Rev. Plant Physiol. Plant Mol. Biol. 52: 527-560.

R.G.D. Steel, Torrie, J.H. and Dickey, D.A. (1997). Principles and Procedures of Statistics: A Biometrical Approach, $3^{\text {rd }}$ edition McGraw Hill Co., New York, USA.

Yadvinder, S., Humphreys, E., Kukal, S.S, Singh, B., Amanpreet, K., Thaman, S., Prashar, A., Yadav, S., Timsina, J., Dhillon, S.S., Kaur, N., Smith, D.J. and Gajri, P.R. (2009). Crop performance in permanent raised bed rice-wheat cropping system in Punjab, India. Field Crops Research 110(1): 1-20.

Snyder, C.S., Bruulsema, T.W., Jensen, T.L. and Fixen, P.E. (2009). Review of greenhouse gas emissions from crop production systems and fertilizer management effects. Agriculture Ecosystems and Environment. 133: 247-266.

Singh Avtar and Kumar Rajneesh. (2014). Tillage with crop residue and nitrogen to enhance the productivity of direct seeded rice. Indian Journal of Agricultural Research. 48: 222-226.

US Salinity Laboratory Staff. (1954). Diagnosis and Improvement of Saline and Alkali Soils. USDA Handbook 60. USDA, Washington, DC.

Wightman, J.L., Duxbury, J.M. and Woodbury, P.B. (2015). Land quality and management practices strongly affect greenhouse gas emissions of bioenergy feed stocks.Bio-Energy Research. 8: 1681-1690.

Xing, G.X. and Zhu, Z.L. (2000). An assessment of $\mathrm{N}$ loss from agricultural fields to the environment in China, Nutrient Cycling in Agroecosystems. 57: 67-73.

Zou, J., Huang, Y., Jiang, J., Zheng, X. and Sass, R.L. (2005). A 3year field measurement of methane and nitrous oxide emissions from rice paddies in China: Effects of water regime, crop residue and fertilizer application. Glob. Biogeochem. Cycles. 19: 153-174. 